\title{
Early Spanish meteorological records (1780-1850)
}

\author{
F. Domínguez-Castro, ${ }^{\text {a* J. M. Vaquero, }}{ }^{\mathrm{a}}$ F. S. Rodrigo, ${ }^{\mathrm{b}}$ A. M. M. Farrona, ${ }^{\mathrm{c}}$ M. C. Gallego, ${ }^{\mathrm{a}}$ \\ R. García-Herrera, ${ }^{c, d}$ M. Barriendos ${ }^{\mathrm{e}, \mathrm{f}}$ and A. Sanchez-Lorenzo ${ }^{\mathrm{g}, \mathrm{h}}$ \\ a Department of Physics, Universidad de Extremadura, Badajoz, Spain \\ ${ }^{\mathrm{b}}$ Department of Applied Physics, Universidad de Almería, Almería, Spain \\ ${ }^{c}$ Departamento Física de la Tierra II, Universidad Complutense de Madrid, Madrid, Spain \\ d Department of Sedimentary Geology and Enviromental Change, Geosciences Institute IGEO (CISC-UCM), Madrid, Spain \\ ${ }^{\text {e }}$ Department of Modern History, Universidad de Barcelona, Barcelona, Spain \\ ${ }^{\mathrm{f}}$ Catalan Institute of Climate Sciences (IC3), Barcelona, Spain \\ ${ }^{g}$ Institute for Atmospheric and Climate Science, ETH Zurich, Zurich, Switzerland \\ ${ }^{\mathrm{h}}$ Department of Physics, Universidad de Girona, Girona, Spain
}

\begin{abstract}
This article summarizes recent efforts on early instrumental data recovery in Spain conducted under the Salvà-Sinobas project. We have retrieved and digitized more than 100000 meteorological observations prior to 1850 in Spain. This data set contains measurements of air temperature, atmospheric pressure, wind direction and state of the atmosphere in 16 places located in Iberia and the Balearic Islands. Most of the observations are made on a daily basis. However, monthly and annual information has also been retrieved. The time coverage of the series is not homogeneous, with the earliest records starting in Seville in 1780. Prior to this work only two series were available in Spain (i.e. Cadiz and Barcelona), so this data set represents a great advance in the early data availability for Spain. Due to the lack of metadata in most of the series, their interpretation must be made with caution.
\end{abstract}

KEY WORDS Iberian Peninsula; early meteorological observations; air temperature; atmospheric pressure; wind; rainfall

Received 28 December 2012; Revised 13 March 2013; Accepted 30 March 2013

\section{Introduction}

The meteorological observations made during the early instrumental period allow us to extend climate data records prior to the industrial revolution at local and regional scales. Moreover, early instrumental series are very useful to extend the overlapping periods with proxies, allowing a better calibration. The early instrumental series, when adequately verified, corrected and homogenized, are useful to understand rare and extreme events. So, the early instrumental observations (EIOs) have received much attention, with a large number of series being retrieved over the last three decades over the world.

Europe is the continent where more EIO have been recovered due to the fact that it holds the richest historical archives. Thus, different initiatives have been developed with the objective of rescuing them as the ADVICE (Luterbacher et al., 1999) IMPROVE (Camuffo and Jones, 2002), HISTALP (Auer et al., 2007), MILLENIUM (Brázdil et al., 2010) and ERACLIM (http://www.era-clim.eu/) projects. As a consequence, the EIO series available in Europe start in the

* Correspondence to: F. Domínguez-Castro, Universidad de Extremadura, Departamento de Física, Avenida de Elvas s/n, 06006, Badajoz, Spain. E-mail: f.dominguez.castro@gmail.com 17th and 18th centuries (see Manley, 1974; Camuffo et al., 2010; Cornes et al., 2012; Camuffo and Bertolin, 2012; Brázdil et al., 2012 and references therein). In other parts of the world the effort and possibilities to recover long EIO series has been smaller. Nevertheless, some initiatives have reported some interesting series, e.g. in Japan (Können et al., 2003; Zaiki et al., 2006), South Korea (Wang et al., 2007), Canadian Artic (Przybylak and Vizi, 2005), the United States (Baron, 1995; van der Schrier and Jones, 2008; Burnette et al., 2010), India (Sontakke and Singh, 1996; Allan et al., 2002; Sontakke et al., 2008), Australia (Gergis et al., 2009), Brazil (Farrona et al., 2012) and Africa (Gallego et al., 2011; Nicholson et al., 2012).

However, some European regions are still poorly covered by EIO. This is the case of the Iberian Peninsula, where the EIO series available are: Barcelona 1780-1989 (Rodríguez et al., 2001), Cadiz 1786-1996 (Wheeler, 1995; Barriendos et al., 2002; Gallego et al., 2008; Rodrigo, 2012), Gibraltar 1777-2010 (Wheeler, 2006; Wheeler, 2007; Wheeler, 2011; Wheeler and Bell, 2012), Lisbon and some short series in Portugal (Alcoforado et al., 2012; Dominguez-Castro et al., 2012). These EIOs are insufficient to characterize a territory with high climate variability due to its geographical position and its complex topography. 
The main aim of this article is to present and make available the EIO recovered in the Iberian Peninsula in the framework of the Salvà-Sinobas project (http://salvasinobas.uvigo.es/index.php/). We show series from 16 locations, among them, some covering a long period with daily resolution, as Madrid (1784-1850) or Valencia (1804-1850).

The article is organised as follows: the second section gives an overview of the development of the meteorology in Spain and explains the main characteristics of the documentary sources where EIO can be found. The third section describes for each of the 16 new series, the time span, observers, variables and metadata, when available. Finally, discussion and conclusions are provided.

\section{Historical context}

Meteorology experienced significant progress in Europe during the second half of the 17 th century. However, in Spain it started to develop only during enlightenment. A good example is that, although the first network of weather stations was established in Europe in 1654 (Rete Medicea), the first Spanish official initiative of this kind occurred in 1858 (Anduaga Egaña, 2012).

After the War of the Spanish Succession (1701-1714) there were some initiatives in pre-enlightenment scholars, also known as 'novatores', for the promotion of scientific research and meteorological observations. Francisco Fernández de Navarrete, physician to Philip V, had the intention to make a network of meteorological observers in Spain but his initiative would not have continuity (García and Giménez, 1985; García Hourcade, 2002).

In the late 18th century, at the peak of the enlightenment, the nascent economic and cultural recovery and attitude of the monarchy allowed the development of activities related to meteorological observation in different areas:

The Spanish Army and Navy: The Spanish Armada generated a movement of interest in astronomy and meteorology aspects due to its obvious application in trans-oceanic navigation. In the city of Cadiz a renewal movement created the School of Midshipmen with an astronomical observatory (Lafuente and Sellés, 1988; González González, 1992). Alejandro Malaspina (1754-1809) and the Minister of Marine in 1790 presented a proposal to create a network of meteorological observatories. This project, like many other initiatives, would be blocked by the Napoleonic Wars (García and Giménez, 1985). Despite many difficulties, the Navy observations in Cadiz were consolidated thanks to the enlightened professional environment existing in the city and the construction of the Royal Navy Observatory in San Fernando (Barriendos et al., 2002).

The Royal Astronomical Observatory of Madrid (1790) was a statewide initiative that had the help of Navy officers from Cadiz. However, the Napoleonic Wars also disrupted this initiative and would only continue its activity since the mid-19th century (López Arroyo, 2004).
Agricultural meteorology and economic societies: In the late 18th century, patriotic societies began to proliferate in Spain receiving the name of Sociedades Económicas de Amigos del Pats. These societies promoted science strongly related to the productive sectors of the country. Therefore, they were interested in meteorology as a support to promote agriculture (Anduaga Egaña, 2012).

Physicians and medical societies: Spanish enlightened physicians were aware of the weather observing initiatives in Europe and its institutional coordination. The second half of the 18th century was relatively peaceful, enabling exchange and dissemination of scientific journals worldwide. A considerable number of doctors started to observe weather in their localities. Facilities were often modest, but their work was methodologically sound using good instruments.

The absence of institutions coordinating effectively the activities of scientists and physicians prevented the actual development of the observations. Additionally, some situations were not favourable for preservation of the observational records. In the transition from 18th to 19th centuries, Spain experienced a traumatic war against revolutionary France (1793-1795), the war against Portugal (1801), the war against the UK (this time allied with France, 1804-1808) and the war against Napoleon (1808-1814). The scientific activities were drastically affected, with destruction of documentation and facilities in war zones. The economic and social situation in Spain did not improve during the first half of the 19th century. In fact, a dynastic conflict originated two civil wars (1833-1840 and 1846-1849).

These factors explain the scarcity of systematic meteorological observations and the problems in accessing the original records. So, very often, local press, compilations and transcriptions are the only available sources, but they do not provide access to basic information about metadata. As a consequence, the preserved documentation is scarce, fragmentary and kept in precarious conditions. The result is a set of widely scattered meteorological series, with short periods of observations, fragmented and with no homogeneous characteristics: each observer had different instruments and working procedures with no continuity in time. For these reasons, tracing and collecting these data is a very time consuming task.

\section{Meteorological observations in Spain (1750-1850)}

EIO from 16 locations have been retrieved in the framework of the Salvà-Sinobas project. Figure 1 shows their spatial distribution.

Figure 2 shows the variables and length of the rescued series. The covered period ranges from few years (Ferrol, Soria and Badajoz) to several decades (Madrid, Valencia and Cadiz). The comparison of these series with current standard observations is problematic due 


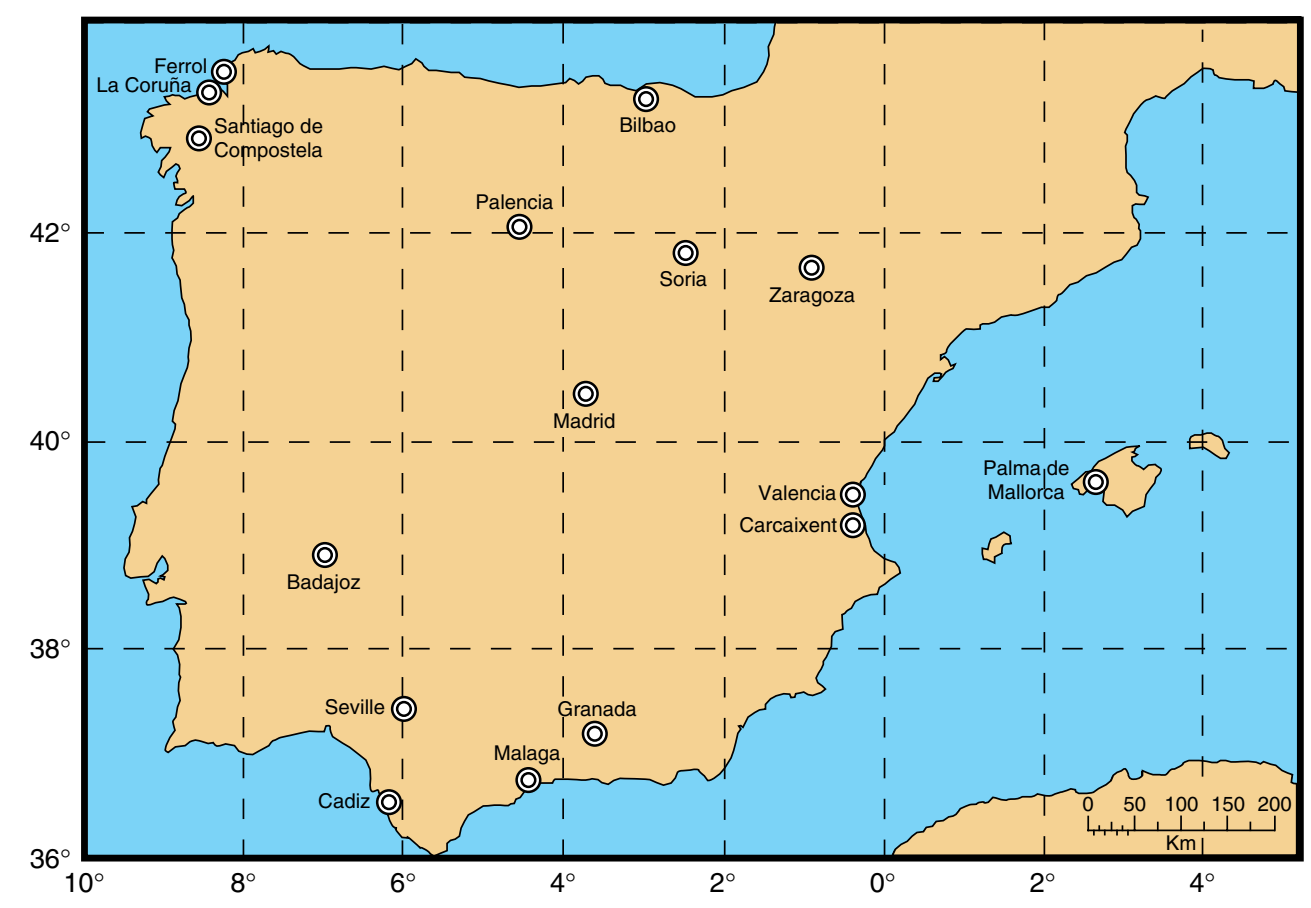

Figure 1. Location of the early instrumental series rescued in Spain.

to the inexistence of overlapping with modern series. Anyway, as shown later, the 100000 or more daily data rescued can be very helpful to characterize specific climatic events or periods in the past. It is also important to note that most of the series are the first known observations for these locations. All of them are freely accessible in the Salvà-Sinobas web page (http://salvasinobas.uvigo.es/index.php/eng/) and in international databases as The International Surface Pressure Databank (http://reanalyses.org/observations/international-surfacepressure-databank) and the International Surface Temperature Initiative (http://www.surfacetemperatures.org/). Next we provide a description of every rescued series using a geographical order from $\mathrm{N}$ to $\mathrm{S}$ and $\mathrm{W}$ to $\mathrm{E}$.

\subsection{Ferrol}

We have located a meteorological record from El Ferrol, from 22 April 1788 to 5 November 1788. Air temperature, weather description, wind force and direction were recorded daily. The observation time is not known, but it is probably at midday. The observer was Manuel Díaz de Herrera, a Spanish Navy Officer. Our source is a manuscript book entitled 'Diario de las Observaciones Astronomicas hechas, en este Observatorio del Ferrol, por los oficiales destinados en él' preserved at the Archive of the Royal Navy Observatory of San Fernando (ARNOSF) (Box 131. Signature 17209).

There are two different readings of temperature. The main reading is made with a 'wine spirit' thermometer with Reaumur scale. Daily readings are available from April 29th until September 4th with some gaps. The other reading is short and was taken with a metal thermometer that was located in a Thiout pendulum. However, both the thermometer readings seem to be erroneous. In fact, Herrera wrote ( 5 November 1788) 'The thermometer that exists in this observatory is useless' and (29 May 1788) 'the metal thermometer is messed up'.

\subsection{La Coruña}

Monthly instrumental observations from January 1844 to December 1846 have been found in 'Diccionario geográfico-estadístico-histórico de España y sus posesiones de ultramar' (Madoz, 1847). A table in volume 7 shows: mean air temperature in Celsius scale; mean atmospheric pressure in Spanish inches and in metres; rainy days; cloudy days; clear days; dominant wind direction and amount of days with this dominant wind direction.

The observer was Benito Sotelo, a medical doctor and Chair of Mathematics in the 'Consulate' so called school of pilots. He took the readings twice a day at 9 a.m. and 12 p.m. in the Panaderas street (current location of the Provincial Museum of Arts).

\subsection{Santiago de Compostela}

Two years of records at Santiago de Compostela (1849-1850) were published by Antonio Casares (1850, 1851). He was the first holder of the Chair of Chemistry at the University of Santiago. Besides meteorological records, he conducted applied research in industry, agriculture and medicine. Moreover, he was a pioneer in chemical analysis and spectroscopy in Spain.

The readings were made four times per day at 9 a.m., 12 p.m., 3 p.m. and 6 p.m. (Local Solar Time, LST) but only monthly data are available. The measurements include atmospheric pressure [minimum ( $\min )$, maximum (max) and mean], air temperature (min, max and mean) 


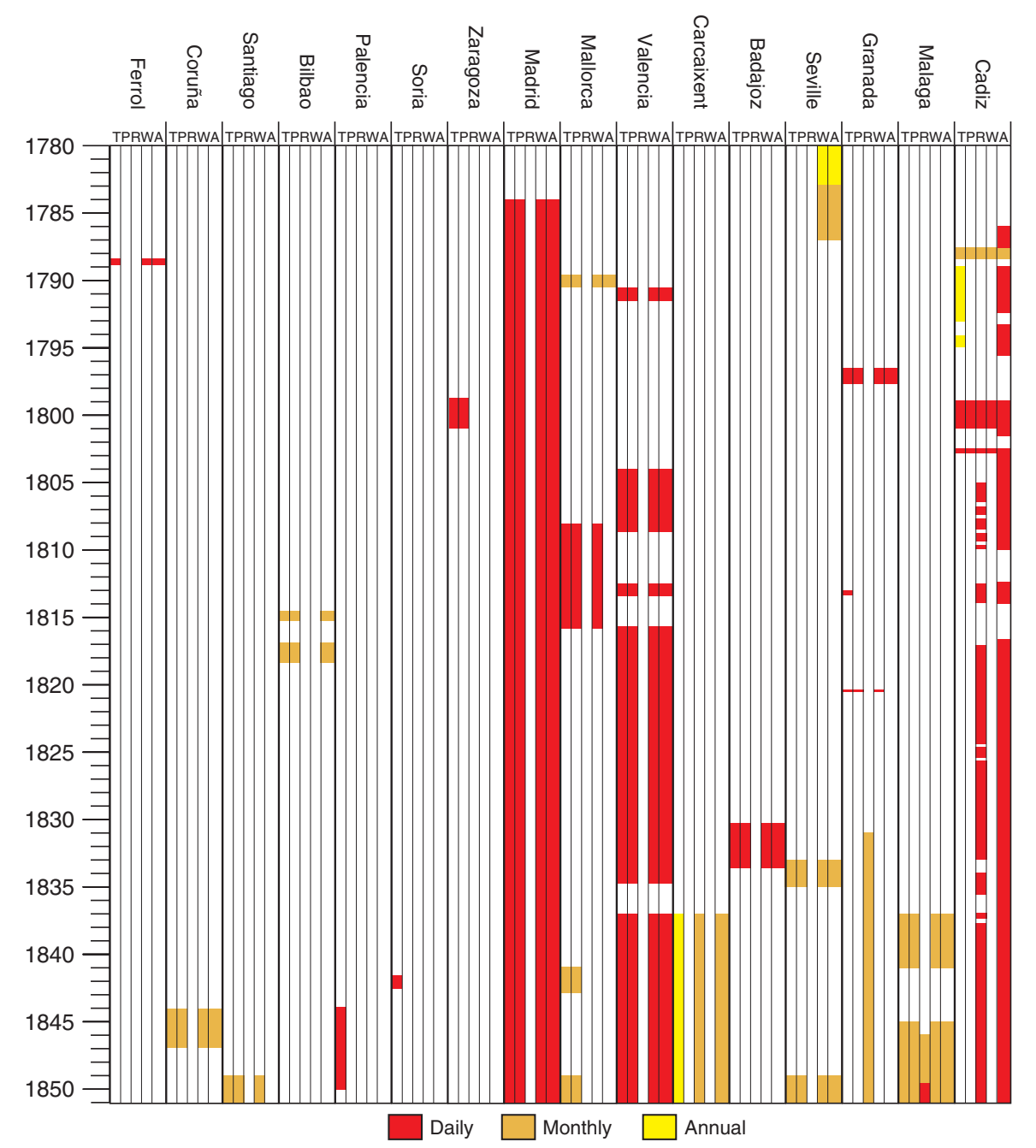

Figure 2. Temporal coverage of the Iberian early instrumental series. Variables: T, air temperature; P, atmospheric pressure; R, rainfall; W, wind direction; A, state of the sky.

and number of rainy days. However, we have little information on metadata. Atmospheric pressure is measured in millimetre and air temperature in Celsius.

\subsection{Bilbao}

José Joaquín de Ferrer was a Spanish astronomer. We have located a manuscript book with geodetic observations made by Ferrer, including some pages with meteorological readings taken at Bilbao. The book is entitled 'Observaciones astronómicas y geodésicas' and is preserved in the ARNOSF with the signature 17270.

Monthly records are available for two periods: August 1814-February 1815 and December 1816-April 1818. The recorded variables are air temperature (min, max and mean), atmospheric pressure (min, max and mean), number of rainy days and number of snow days. Unfortunately, there are no metadata about instruments or methodology and only numerical tables are available.

\subsection{Palencia}

These measurements were found in a folder in the Archives of the Royal Academy of Medicine of Madrid
(ARAMM) (signature 12-8-Molina-31). This manuscript contains meteorological information from different places and dates, some of them studied in this article i.e. Soria (see next subsection). These manuscripts were compiled by Manuel Rico Sinobas.

The measurements are daily air temperature observations in Reaumur scale from 1 January 1844 to 11 December 1849 with a small gap from 4 May 1844 to 15 November 1844 . The measurements were taken two times a day, at dawn (from 5 a.m. to 8:30 a.m., being 7:30 a.m. the most common time) and at night at 11 p.m. The observer and the precise location of the observatory are unknown.

\subsection{Soria}

These meteorological observations were extracted from a Manuel Rico Sinobas's manuscript (ARAMM, signature 12-8-Molina-31). Temperature measurements in Soria were taken three times a day ( 6 a.m., 2 p.m. and 11 p.m.) from 6 July 1841 to 31 March 1842 . The record is continuous except for a small gap from 16 January 1842 to 1 February 1842 . These measurements appear without 
any reference to the instrument used or measurement procedures. However, a comparison (not shown) with the modern observations (1943-2011) of Soria station $\left(41^{\circ} 46^{\prime} 30^{\prime \prime} \mathrm{N} ; 2^{\circ} 28^{\prime} 59^{\prime \prime} \mathrm{W}\right)$ makes clear that the scale used in the early measurements is Reaumur.

\subsection{Zaragoza}

The daily meteorological data appear in the newspaper 'Diario de Zaragoza' from 30 December 1798 to 31 December 1800. For unknown reasons, the publication of the meteorological observations was stopped in 1801 .

Details of the observatory location and instruments are unknown. The Newspaper mastheads showed the meteorological data in small diary tables. Three-daily measurements of atmospheric pressure and air temperature, taken at 7 a.m., 2 p.m. and 10 p.m. (LST) were included. However, there were some months in which temperature and pressure observations were not made. Temperature data show gaps during the second half of the years 1798 and 1800; pressure from March 1798 until March 1798, from May 1799 until December 1789, and in the first half of 1800 .

Temperature data were taken in Reaumur scale and observations of atmospheric pressure were made with a barometer graduated in Paris inches and lines.

\subsection{Madrid}

The observations retrieved here come from two sources:

Rico Sinobas Manuscripts: Manuel Rico Sinobas was doctor in Physics and Medicine. He was member of the Royal Academy of Exact, Physics and Natural Sciences (since 1852) and of the Royal Academy of Medicine (from 1861). Rico Sinobas was the first to recognize the potential of the documentary sources in the study of climate in Spain. He compiled early instrumental measurements and natural hazards.

In this subsection we focus on his compilation of instrumental series from Madrid, (ARAMM, manuscripts Manuel Rico Sinobas, signatures 12-8-Molina-4/26, 23 vols.). These manuscripts are meteorological observations that Rico Sinobas transcribed from different documents. Frequently, it is difficult to know the observer, the precise location of the observatory or the observational methodology. In general, three periods can be identified:

1786-1804: These records are very discontinuous with important gaps. Pedro Alonso Salanova was responsible for the measurements during the first years (García Couto, 2011). Since 1790 they were made under the direction of Salvador Jiménez Coronado. The measurements during the last years of the period were taken by Juan López de Peñalver in the Real Gabinete de Máquinas del Buen Retiro.

1803-1829: This is the most complete and uniform period, with very short gaps. On the other hand we have no information about the observers or the place where the measurements were taken.

1830-1850: Another period with important gaps and discontinuities. During the 1830 s the measurements were taken in the 'Conservatorio de Artes' in the Turco Street 9 and 10 (currently, Marques de Cubas Street). During the early 1840s the observations were made by Mr. Campo in the Astronomical Observatory in the Retiro's Park $\left(14^{\circ} 44^{\prime} 97^{\prime \prime} \mathrm{W} 40^{\circ} 24^{\prime} 30^{\prime \prime} \mathrm{N}\right)$. During the last years of this period the measurements were infrequent and it is unclear where were taken.

Newspapers readings: The gaps in the Rico Sinobas compilation have been filled with daily observations from newspapers.

The first measurements appeared in 1784 in the 'Memorial Literario, Instructivo y Curioso de la Corte de Madrid' founded by Pedro Pablo Trullenc and Joaquín Ezquerra. The Memorial frequently published articles from different sciences such as botany, physics, chemistry, geology, ... The daily meteorological measurements were taken at 7 a.m. or 8 a.m. and were followed by a qualitative summary of the meteorological conditions and a report of the diseases during the month. The meteorological variables reported were atmospheric pressure, air temperature, wind direction and state of the atmosphere.

In 2 September 1786 meteorological measurements started to appear in the mastheads of the daily newspaper 'Diario curioso economico y comercial'. This newspaper was edited by Santiago Thewin, a German naturalized Spanish with his office at Puerta del Sol. Although its name and editors were changing, e.g. 'Diario de Madrid', 'Diario de avisos de Madrid' or 'Diario Oficial de Avisos de Madrid' the newspaper provides meteorological observations until 1917 when it disappeared.

Overall, the meteorological measurements of the newspapers show a similar pattern with three daily observations (mainly 7 a.m., 12 p.m. and 5 p.m.) of air temperature, atmospheric pressure, wind direction and state of the atmosphere (cloudy, rainy, clear, ... ), but no metadata appear in the text. Sometimes, but not always, the values of the variables are coincident with the Rico Sinobas records.

\subsection{Mallorca}

Monthly summaries of meteorological observations are recorded in the 'Semanario Económico', from November 1789 to September 1790. They consist of air temperature (max and min) in Reaumur degrees, atmospheric pressure in French inches and lines and number of clear, cloudy, windy, rainy and snowy days. Monthly predominant wind directions are also recorded.

The newspapers 'Diario de Mallorca' (1808-1814), 'Diario de Palma' (1811-1813) and 'Diario Balear' (1814-1815) published daily data taken at 7 a.m., 12 p.m. and 5 p.m. of air temperature (Reaumur), atmospheric pressure (French inches and lines) and wind direction (8 points), but a preliminary quality check indicates that the data are not very reliable (gaps, repetition of data in successive days, etc.).

Data published in 'Revista Balear' (1843-1844) seem more reliable. This weekly journal published a summary 
of monthly amount of rainfall and number of rainy days corresponding to 1841-1842, and daily data taken at 6 a.m. 12 p.m. and 10 p.m. from 29 October 1843 to 24 August 1844. These data are air temperature (Reaumur) and atmospheric pressure (French inches and lines).

In 1854, the medical doctor Fernando Weyler y Laviña, published a medical topography (Weyler y Laviña, 1854) dedicated to the Balearic Islands. In this book, the author included a chapter devoted to meteorology, with monthly summaries of air temperature (max and min) in Reaumur degrees, atmospheric pressure in French inch and lines and relative humidity for the period 1849-1853. This text also contains seasonal summaries of amount of rainfall and number of rainy days for the period $1830-1835$, as well as comments on some extreme events recorded in Mallorca during the 1840s.

\subsection{Valencia}

The first evidence of meteorological observations in the city of Valencia is dated in mid-18th century. These EIO should be attributed to Manuel Rosell y Viciano, a physicist and ecclesiastic from the order of Saint Augustine (Justo Pastor, 1830). Unfortunately, it was not possible to locate these observations in the civil and religious archives of the city.

It is necessary to wait until 1790 for new evidence of meteorological observations in Valencia. They were included in the newspaper entitled 'Diario de Valencia' (1790-1835) since the beginning of its daily publication on 29 June 1790. For unknown reason the observations were not included since 29 May 1791 until 1 January 1804.

The observer was Francisco Antonio Espinós, a local clockmaker of Valencia who made the observations from his house at the Santa Catalina square in the city centre. A detailed description of the observatory is not provided, but some metadata about the observations and instrument are described in different days of the publication.

Initially, four-daily observations taken at 8 a.m., 1 p.m., 4 p.m. and 8 p.m. LST were published in tables included in the first or second page of the newspaper. On 29 September 1790 the last two observations were replaced by one at 5 p.m. LST. Afterwards, the tables remain with three times per day with slight changes in the hours of the observations. Each daily observation included five variables: air temperature (Reaumur scale), atmospheric pressure (in inches and lines), humidity (with a hygrometer made by the observer and expressed in 24 degrees of humidity, see description below), wind direction (in 32point compass) and state of the atmosphere (e.g. clear, cloudy, windy, rainy, etc.). Equally, for some days a brief text appeared below the table describing an extreme weather event (e.g. storms, snowfalls, etc.), and, until 1808, rainfall data (in inches and lines).

On 10 April 1804, in the Diario de Valencia Espinós described his hygrometer. It was a remaking of the type invented by Francesco Folli (1624-1685) in 1660 (Figure 3). This hygrometer is based on the physical principle that a paper strip shrinks or stretches when relative
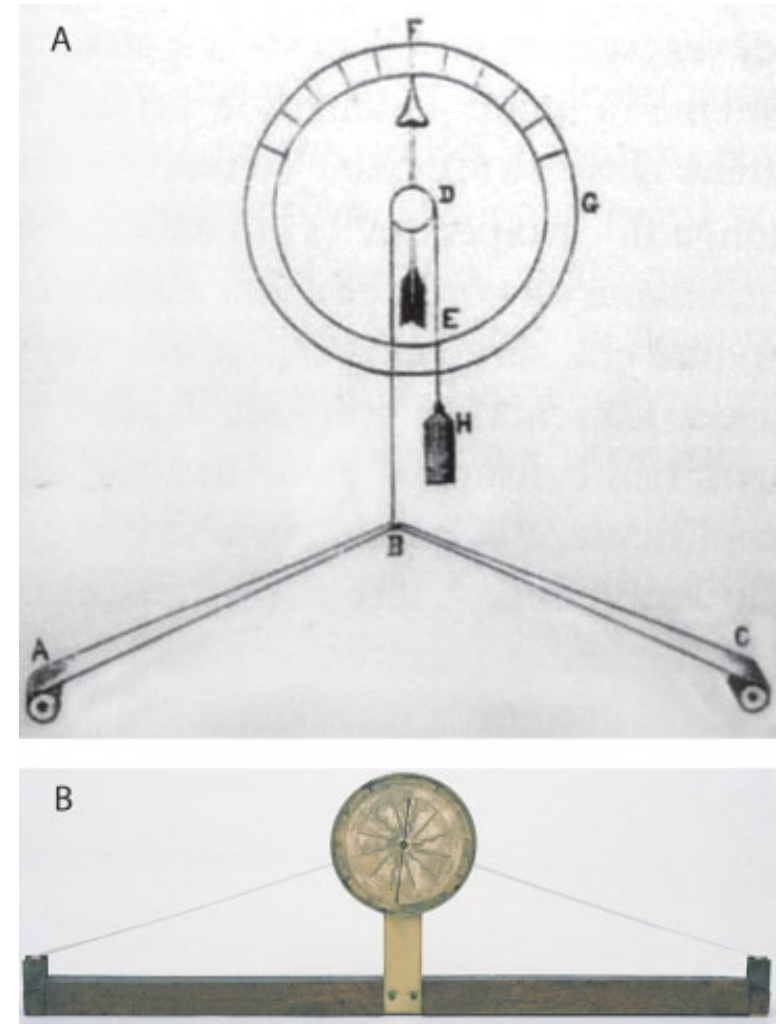

Figure 3. (A) Drawing of the Folli hygrometer (from Borchi and Macii 2009), (B) Folli's paper-ribbon hygrometer (by courtesy of Museo Galileo, Firenze, inv. 2434).

humidity changes. The earliest detailed description of the instrument was made by Vincenzo Viviani (1622-1703) in 1665 (Borchi and Macii, 2009). Espinós improved the sensitivity of the Folli hygrometer including a gear composed of two cogwheels having 30 and 10 cogs, respectively to magnify the strip dimensional changes. The improvement increased by three times the sensitivity of the Folli hygrometer. The scale of the Espinós hygrometer was divided in 24 degrees, i.e. 12 for humidity and 12 for dryness.

The observations were suddenly stopped on 10 August 1834, which was justified because the observer was temporarily indisposed. Nevertheless, the observations were missing until the end of the 'Diario de Valencia' on 6 May 1835. Espinós cannot be found any more in the census of Valencia, which suggests that he probably died around these dates.

Meteorological observations appeared again in 1837 in the newspaper entitled 'Diario Mercantil de Valencia' (1833-1872). Curiously, the table with the data contains the same format (three-daily observations and variables) as in the previous newspaper, the Folli hygrometer was also used. Consequently, one reasonable hypothesis is that a relative, colleague or disciple of Espinós continued the meteorological observations in the city of Valencia. In 1841, the Folli's hygrometer is replaced by a Saussure's instrument. This series was published anonymously until 15 June 1863. Since then, the newspaper included the 
official meteorological observations made at the University of Valencia, which in fact was established 5 years before, in 1858 .

These observations, jointly with those from Madrid help to improve our knowledge of the Tambora effects in Iberia. The Tambora eruption took place in April 1815, and the most identifiable impact in the meteorology of Europe was an important decrease in temperatures during the summer of 1816 (Harington, 1992). The impact of the Tambora eruption in the Iberian Peninsula weather was studied by Trigo et al. (2009). They found a cold anomaly of $2-3{ }^{\circ} \mathrm{C}$ in July and August of 1816 (with the 1871-1900 period used as reference) in four Iberian series.

Figure 4 shows the monthly anomalies of the midday measurements of the new raw series of Madrid (used only partially by Trigo et al., 2009) and Valencia around 1816. The monthly departures have been calculated for the periods 1803-1829 (Madrid) and 1815-1834 (Valencia). The observations during these periods come from only one documentary source and show the same times of observation and variables during the whole period. So, we consider that the methodology of observation was the same during both periods.

As we expect, the 'year without summer' is clearly recorded in both series (Madrid and Valencia) showing a significant negatives departures during the summer of 1816.

It is remarkable that both series show similar trends during the overlapping period (June 1816-December 1829). The temperature drop during the summer of 1816 is clear in Valencia and probably affected all the SE of Iberia. In Madrid and Valencia there are negative departures since June 1815-December 1816, but the largest departures occurred during July and August 1816. It is interesting to note that Valencia in September shows a departure as great as in July and August but in Madrid the temperature had already recovered.

\subsection{Carcaixent}

Salvador Bodí y Congrós made systematic meteorological readings from 1837 to 1879 in Carcaixent (close to Valencia). A manuscript book written by Bodí y Congrós is preserved in the Library of the University of Valencia. We have consulted a partial modern edition (Bodí y Congrós, 1986), which reproduces all the meteorological data of the manuscript. Unfortunately, others manuscripts with the original meteorological records taken by Bodí y Congrós are lost.

Bodí y Congrós provides some metadata on their instruments. The thermometer was always the same. It has Reaumur scale, although a Celsius scale was added. He indicates that the rain gauge had a zinc glass of about $30 \mathrm{~cm}$ height. He used a thin rod made of walnut wood that was marked in millimetres to measure the height of the water column.

Only three long series can be recovered from the unique manuscript preserved: (1) annual absolute maximum and minimum air temperatures (1837-1851), (2) monthly number of clear days in the morning and afternoon (1837-1879) and (3) monthly precipitation (1837-1879).

\subsection{Badajoz}

The earliest known instrumental records of Badajoz appeared in the newspapers 'Diario de Badajoz' (from 1 March 1830 to 29 June 1833) and 'Boletin Oficial y de Avisos de Estremadura' (form 30 June to 19 July 1833). The Captain General José Sanjuan founded this publication 'as a means to propagate the improvements of human intelligence'. However, a complete collection of these newspapers has not been preserved (Pulido and Nogales, 1989) and the existing collections show some gaps.

The meteorological variables recorded are air temperature, atmospheric pressure, wind direction and state of the atmosphere. Three daily meteorological observations were recorded at 7 a.m., 12 p.m. and 5 p.m. in winter and at 6 a.m., 12 p.m. and 6 p.m. in summer. We have no information about the exposure conditions of the meteorological instruments and no description of the instruments is available.

Temperature data were recorded on a Reaumur scale with an error of $\pm 1{ }^{\circ} \mathrm{R}$. Pressure data were given in inches and lines, with an error of \pm 0.5 lines. However, we do not know what kind of inches was used. Sixteen points were distinguished for wind direction. Moreover, the source established six categories (clear, cloudy, partially cloudy, mist, rain and snow) to describe the state of the atmosphere.

\subsection{Seville}

There are various texts related to Seville at the end of the 18th century, written by Nieto de Piña (Nieto de Piña 1785, 1786, 1787) a medical doctor, member of the Academy of Medicine of this city. The author describes the appearance of different diseases during the period 1784-1786, relating them with the rainfall regime during the previous years. Although rainfall quantitative measurements are not provided, the number of annual rainy days and the predominant wind direction observed in the city during the period 1778-1782 are recorded. After this date, since January 1783, his description is more detailed, with monthly resolution until December 1786. During the last year, he provides temperature data and storms of certain critical days.

There is a article published in 1851 by Miguel Colmeiro (1816-1901), member of various scientific societies and author of numerous botany treatises with monthly data from Seville published in the newspapers corresponding to the years 1833, 1834, 1849 and 1850 (Colmeiro, 1851). Data are monthly mean minimum and maximum temperature (Reaumur), mean pressure (French inches and lines), mean relative humidity (\%), number of rainy days and predominant wind direction.

These data increase the evidence of the unusual weather at the beginning of the 1780s in the Iberian 


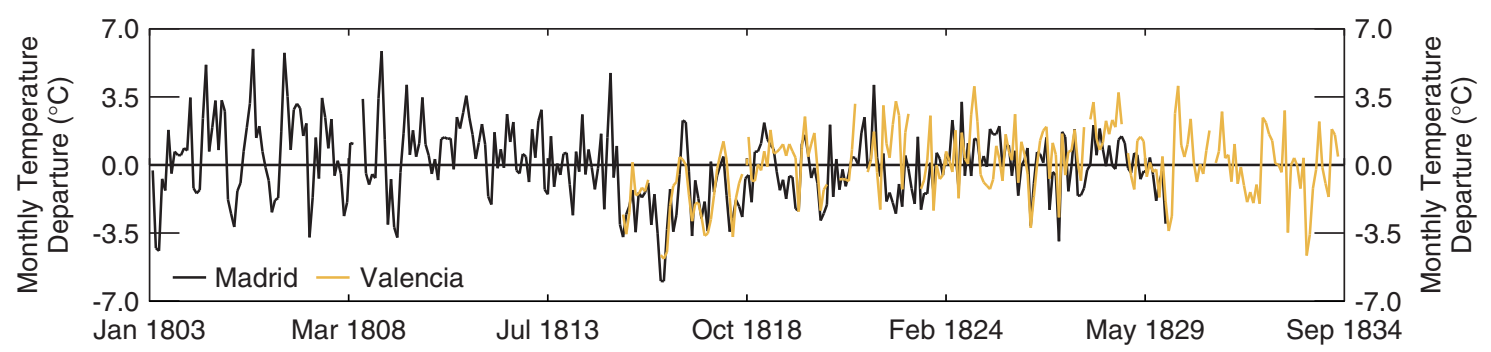

Figure 4. Temperature departure of Madrid with respect to the average of the 1803-1829 period and for Valencia with respect to the 1815-1834 period.

Atlantic coast detected by Alcoforado et al. (2012). In fact, Kington (1988) established almost 25 years ago that the 1780s contained extreme precipitation anomalies. Brázdil et al. (2010) have pointed catastrophic floods in Central Europe during the winter and spring of 1783-1784, due to heavy rains and snowmelt, and flooding in southern France due to continuous rains. This anomalous winter $1783 / 1784$ has been related to the eruption of the Laki since 8 June 1783 to February 1784. It provoked a widespread sulphuric aerosol cloud (i.e. dry fog) that effected livestock, vegetation and people in Europe causing important social and economic impacts (Highwood and Stevenson, 2003; Thordarson and Self, 2003). But it is not clear that the Laki eruption was the cause of the anomalous climate during this period. According to D'Arrigo et al. (2011) the anomalous weather could be explained by the occurrence of a negative North Atlantic Oscillation in combination with El Niño-Southern Oscillation warm event and not by the Laki eruption.

Alcoforado et al. (2012) shows the available annual precipitation series in Portugal for the 1780s (i.e. Lamego, Mafra and Lisbon, all of them seaside towns). The three locations show an extremely rainy period between 1784 and 1789. These observations are in accordance with the monthly rainy days of Gibraltar (Wheeler and Bell, 2012) and the Nieto de Piña data shown in Figure 5.

The number of monthly rainy days in Gibraltar and Seville for the period 1783-1786 are highly correlated. The Pearson correlation coefficient is equal to 0.86 ( $p$ value $<0.001)$. So thanks to these new evidences we know heavy precipitation was also recorded inland during 1783-1786.

\subsection{Granada}

The meteorological measurements have been extracted from the 'El Mensagero' newspaper, published in Granada from 2 June 1796 to 28 September 1797. It was edited by the mathematician Francisco Dalmau, author of a topographic map of the city published in 1796 (Dalmau, 1796), and member of the Academy of Science of Barcelona. This journal appeared twice a week, on Monday and Thursday. Meteorological information consists in daily data taken at noon of air temperature (Reaumur scale with an error of $\pm 1{ }^{\circ} \mathrm{R}$ ), atmospheric pressure (inches and lines, error \pm 0.5 lines), wind direction (16-point compass) and state of the atmosphere, such as cloudiness, rainfall, storms, fogs, etc. The meteorological data cover without gaps, the period between 28 May 1796 and 25 September 1797.

In the first decades of the 19th century, we have found very short records corresponding to newspapers. The 'Diario de Granada. El Publicista' was published since 1 November 1812, and it has meteorological data for the period between 8 January 1813 and 26 February 1813. Data are air temperature taken at 12 p.m. with a Reaumur thermometer (error $\pm 0.1^{\circ} \mathrm{R}$ ). The 'Diario Constitucional de Granada' started on 24 March 1820, and it only contains meteorological data corresponding to the month of July 1820. In this case data (air temperature in Reamur scale with an error $\pm 0.5^{\circ} \mathrm{R}$, atmospheric pressure in French inches and lines, error \pm 0.5 lines and wind direction with an 16-point compass) were taken three times a day, at 7 a.m., 12 p.m. and 3 p.m. The main problem is the lack of information on the conditions of observation, the methods and instruments used by each observer and their precise location.

We also recovered the monthly rainfall days in Loja (Granada province) from 1831 to 1854 (Due Rojo, 1944). The observational record was kept by Victoriano Caro y Nogales, priest of the Santa Catalina de Loja church during the observational period.

\subsection{Málaga}

In 1852, V. Martínez y Montes, member of the Academies of Medicine of Madrid, Granada, and Málaga, published his topography on Málaga (Martínez y Montes, 1852). In this text he includes meteorological data of the city, with detailed descriptions of metadata. Among the observations he includes data published in local newspapers, observations made by Guillermo Shortliffe (British medical doctor who lived in Málaga during 30 years) and himself. Air temperature data are presented by the author in Celsius scale, atmospheric pressure in French inches and millimetre of mercury and rainfall in Spanish inches and millimetre. Other observations (wind direction and state of the atmosphere) are presented in tables indicating the monthly frequency. Data correspond to the period $1837-1848$ with a gap in 1842-1844, for all the variables except rainfall. For rainfall, the author includes total amounts from 


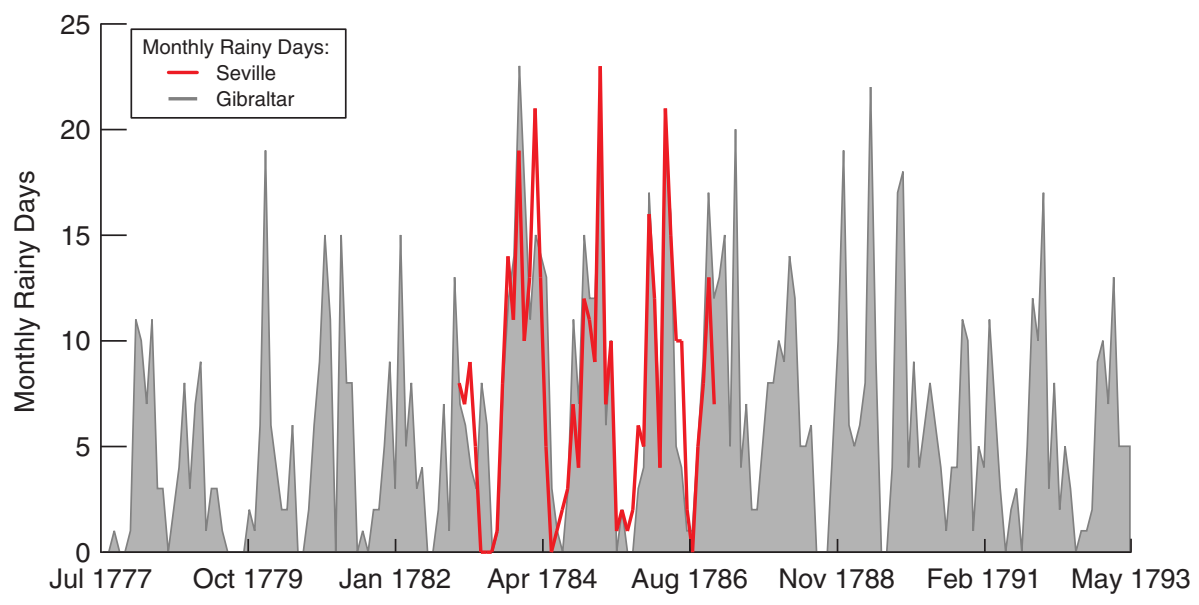

Figure 5. Monthly rainy days from Seville (red line, newly rescued data) and Gibraltar (grey area, provided by Wheeler and Bell, 2012).

September to December and from January to August from 1846 to 1851, and daily amounts from September 1849 to August 1851.

Temperature measurements $(1837-1848)$ were taken three times a day ( 7 a.m., 12 p.m. and 5 p.m.) 'in the middle of the city, in the shadow in the open air'. Monthly and annual mean values were obtained using the procedure explained by Kaemtz (1843), based on the difference between daily maximum and minimum temperature.

Temperature measured by Shortliffe was used by numerous scientific works of the mid-19th century (see McDougall, 1851; Rochester, 1851; Lee, 1855; ScoresbyJackson, 1862).

Atmospheric pressure data are presented as monthly mean of the complete period (1837-1848). A French barometer was used, located indoor in the middle of the city, and 'some' metres above sea level. The author indicates that the 'reduction to zero temperature was not made, because the differences would be very small'.

Wind direction was observed in the harbour of the city and using the weathercock of the cathedral tower (in the middle of the city). An 8-point compass was used, and the source includes the monthly frequency in the same time period.

\subsection{Cadiz}

There are some works in the literature dedicated to study early instrumental series in Cádiz, but most of them focus on temperature, pressure or wind data (Wheeler, 1995; Barriendos et al., 2002; Gallego et al., 2008; Rodrigo 2012).

We have rescued the rainfall and days of rain of the Royal Navy Observatory of San Fernando, the Urrutia brothers record in Cadiz centre and some newspapers like Diario Mercantil, El Globo, El Comerico, El Nacional, Nuevo Defensor del Pueblo, Redactor General and El Tiempo (from a detailed description of the documentary sources consulted see Barriendos et al., 2002). The distance between the observatories is only $10 \mathrm{~km}$. The series retrieved are daily rainfall in millimetres from 1805 with some gaps in the early years 1810-1812, 1814-1816, 1833 and 1835-1836. Previous to these dates we have retrieved the days of rain from 1786 to 1805 with important gaps in 1787-1788, 1792, 1795-1798 and 1802 .

The gap of 1787-1788 has been partially filled at monthly resolution thanks to the newspaper Memorial Literario that shows monthly meteorological data from Cádiz from December 1787 to March 1788 taken by Sánchez Buitrago. Data consist in a brief monthly summary of the evolution of barometric (French inches and lines) and temperature (Reamur degrees) readings, indicating absolute monthly maximum and minimum values, as well as predominant wind and atmospheric conditions (cloudiness, rainy days, fog and storm days).

Other meteorological observations have been rescued from Arejula (1806). This book is a complete description of the development of a yellow fever epidemic at the beginning of the 19th century. It includes a long chapter showing daily meteorological observations corresponding to 1799 and 1800 (air temperature, atmospheric pressure, wind direction and state of the atmosphere), taken in the city by a private observer called Josef María Chacón at midday, and data from January to October 1803, taken by Aréjula (same variables but taken three times a day). He added tables comparing with previous data from 1789 to 1794 (except 1793) but they only show the absolute maximum temperature of each year.

\section{Discussion and conclusions}

As one of the final results of the Salvà-Sinobas project, we have presented in this paper the recovery of a large amount of weather data for the period 1780-1850 in Spain that increases the availability of meteorological data for this period. Following the completion of the project the number of available series has increased considerably (see Figure 2). In fact, we have rescued three long series, Madrid (air temperature, atmospheric pressure, state of the atmosphere and wind direction, three 
times per day), Valencia (air temperature, atmospheric pressure, state of the atmosphere, humidity and wind direction, three times per day), and the daily precipitation of Cadiz. These series have an almost complete coverage of the period 1790-1850. Additionally, 13 shorter series have been rescued, allowing time intervals with up to eight contemporary meteorological series (i.e. during the 1840s).

The main problem with the recovered series is the lack of information on instruments and methods of observation, mainly because most of the series are based on data collected from daily newspapers of the time. Another problem is that in Spain no long homogenized series exist, i.e. prior to 1850 , to be used for comparison. Therefore, it is impossible to perform data correction and homogenization. However, this type of data are useful for some specific weather and climate studies, e.g. Trigo et al. (2009) for the year without summer in Iberia, Alcoforado et al. (2012) on the relationship between the NAO index and precipitation in Iberia in the 18th century, Vaquero et al. (2008) and DominguezCastro et al. (2012) analysing tropical hurricanes similar to Vince 2005.

In this article, a considerable progress has been made in the availability of meteorological observations prior to 1850 in Spain. But this work is also an acknowledgement to all the observers who took these measurements during the 18th and 19th centuries. This task was made by official or private initiatives but ever with a great dedication, in times of important difficulties for the development of science in Spain. So we are very proud of making visible the work of these observers two centuries later. Their work has allowed us to generate an early instrumental data base that represents a breakthrough in the availability of data from this period in Spain.

\section{Acknowledgements}

This work has been financed by the Ministry of the Environment, Rural and Maritime Affairs of Spain 'SalvàSinobas project: Climatic Variability Characterization in the Iberian Peninsula during the Period 1750-1850' (ref. 200800050083542) and the Spanish Science and Innovation Ministry (AYA2011-25945). The last author was supported by a postdoctoral fellowship from the 'Generalitat de Catalunya i del programa Cofund de les Accions Marie Curie del 7è Programa marc d'R+D de la Unió Europea' (2011 BP-B 00078). We would like to thanks all the staff of the archives and libraries cited in the text, whose help made this work possible. We would also like to thank the two anonymous reviewers for their positive and constructive comments.

\section{References}

Alcoforado MJ, Vaquero JM, Trigo RM, Taborda JP. 2012. Early Portuguese meteorological measurements (18th century). Climate of the Past 8: 353-371.
Allan RJ, Reason CJC, Carroll P, Jones PD. 2002. A reconstruction of Madras (Chennai) mean sea-level pressure using instrumental records from the late 18th and Early 19th centuries. International Journal of Climatology 22: 1119-1142.

Anduaga Egaña A. 2012. Meteorología, ideología y sociedad en la España contemporánea. Consejo Superior de Investigaciones Científicas: Madrid.

Arejula JM. 1806. Breve descripción de la fiebre amarilla padecida en Cádiz y pueblos comarcanos en 1800, en Medinasidonia en 1801, en Malaga en 1803, y en esta misma plaza y varias otras del reyno en 1804. Biblioteca de Andalucía, Sgn.: ANT-XIX-614.

Auer I, Böhm R, Jurkovic A, Lipa W, Orlik A, Potzmann R, Schöner W, Ungersböck M, Matulla C, Briffa K, Jones PD, Efthymiadis D, Brunetti M, Nanni T, Maugeri M, Mercalli L, Mestre O, Moisselin J-M, Begert M, Müller-Westermeier G, Kveton V, Bochnicek O, Stastny P, Lapin M, Szalai S, Szentimrey T, Cegnar T, Dolinar M, Gajic-Capka M, Zaninovic K, Majstorovic Z, Nieplova E. 2007. HISTALP - historical instrumental climatological surface time series of the greater Alpine region 1760-2003. International Journal of Climatology 27: 17-46.

Baron WR. 1995. Historical climate records from the northeastern United States, 1640 to 1900 . In Climate Since A.D. 1500 . Routledge: New York; 24-91.

Barriendos M, Martín-Vide J, Peña JC, Rodríguez R. 2002. Daily meteorological observations in Cádiz-San Fernando. Analysis of the documentary sources and the instrumental data content (1786-1996). Climatic Change 53: 151-170.

Bodí y Congrós S. 1986. El Clima de la Ribera en el siglo XIX. Ayuntamiento de Carcaixent: Carcaixent.

Borchi E, Macii R. 2009. Meteorologia a Firenze. Nascita ed Evoluzione. Pagnini Editore: Firenze.

Brázdil R, Demarée GR, Deutsch M, Garnier E, Kiss A, Luterbacher J, Macdonald N, Rohr C, Dobrovolný P, Kolár P, Chromá K. 2010. European floods during the winter 1783/1784: scenarios of an extreme event during the 'Little Ice Age'. Theoretical and Applied Climatology 100: 163-189. DOI: 10.1007/s00704-009-0170-5

Brázdil R, Zahradníček $P$, Pišoft $P$, Štěpánek $P$, Bělínová $M$, Dobrovolný P. 2012. Temperature and precipitation fluctuations in the Czech Republic during the period of instrumental measurements. Theoretical and Applied Climatology 110: 17-34. DOI: 10.1007/s00704-012-0604-3

Burnette DJ, Stahle DW, Mock CJ. 2010. Daily mean temperature reconstructed for Kansas from early instrumental and modern observations. Journal of Climate 23: 1308-1333.

Camuffo D, Bertolin C. 2012. The earliest temperature observations in the world: the Medici Network (1654-1670). Climatic Change 111(2): 335-363.

Camuffo D, Jones P. 2002. Improved understanding of past climatic variability from early daily European instrumental sources. Climatic Change 53(1-4): 2002.

Camuffo D, Bertolin C, Barriendos M, Dominguez-Castro F, Cocheo C, Enzi S, Sghedoni M, Valle A, Garnier E, Alcoforado MJ, Xoplaki E, Luterbacher J, Diodato N, Maugeri M, Nunes F, Rodriguez R. 2010. 500-year temperature reconstruction in the Mediterranean Basin by means of documentary data and instrumental observations. Climatic Change 101: 169-199.

Casares A. 1850. Meteorología. Observaciones hechas en Santiago el año de 1849. Revista de los progresos de las Ciencias Exactas, Físicas y Naturales 1: 19-22.

Casares A. 1851. Resumen de las observaciones meteorológicas hechas en la universidad de Santiago en el año de 1850. Revista de los progresos de las Ciencias Exactas, Físicas y Naturales 2: 105-107.

Colmeiro M. 1851. Observaciones hechas en Sevilla sobre la florescencia y los estados atmosféricos bajo cuyo influjo se verifica. Revista de los Progresos de las Ciencias 2: 555-572.

Cornes RC, Jones PD, Briffa KR, Osborn TJ. 2012. Estimates of the North Atlantic Oscillation back to 1692 using a ParisLondon westerly index. International Journal of Climatology 33(1): 228-248. DOI: 10.1002/joc.3416

D'Arrigo R, Seager R, Smerdon JE, LeGrande AN, Cook ER. 2011. The anomalous winter of 1783-1784: was the Laki eruption or an analog of the 2009-2010 winter to blame? Geophysical Research Letters 38: L05706.

Dalmau F. 1796. Mapa topográfico de la ciudad de Granada. Archivo Municipal Ayuntamiento de Granada, Sgn.: 005.001.003.

Dominguez-Castro F, Trigo RM, Vaquero JM. 2012. The first meteorological measurements in the Iberian Peninsula: evaluating the storm of November 1724. Climatic Change. DOI: 10.1007/s10584-0120628-9 
Due Rojo A. 1944. Un curioso documento meteorológico del siglo XIX. Revista de Geofísica 8(2): 422-427.

Farrona AMM, Trigo RM, Gallego MC, Vaquero JM. 2012. The meteorological observations of Bento Sanches Dorta, Brazil: 1781-1788. Climatic Change 115: 579-595. DOI: 10.1007/s10584-012-0467-8

Gallego D, Garcia-herrera R, Calvo N, Ribera P. 2008. A new meteorological record for Cádiz (Spain) 1806-1852: implications for climatic reconstructions. Journal of Geophysical Research-Atmospheres 112(12): D12108. DOI: 10.1029/2007JD008517

Gallego MC, Domínguez-Castro F, Vaquero JM, García-Herrera R. 2011. The hidden role of women in monitoring nineteenth-century African weather: instrumental observations in Equatorial Guinea. Bulletin of the American Meteorological Society 92: 315-324.

García Couto MA. 2011. Iberian Climate Atlas. Agencia Estatal de Meteorología: Madrid.

García L, Giménez JM. 1985. Notas para la Historia de la Meteorología en España. Instituto Nacional de Meteorología: Madrid.

García Hourcade JL. 2002. La Meteorología en la España ilustrada y la obra de Vicente Alcalá Galiano. Biblioteca de Ciencia y Artillería: Segovia.

Gergis J, Karoly D, Allan R. 2009. A climate reconstruction of Sydney Cove, New South Wales, using weather journal and documentary data, 1788-1791. Australian Meteorological and Oceanographic Journal 58(2): 83-98.

González González FJ. 1992. El Observatorio de San Fernando (1831-1924). Ministerio de Defensa: Madrid.

Harington CD. 1992. The Year without a Summer?: World Climate in 1816. Canadian Museum of Nature: Ottawa.

Highwood EJ, Stevenson DS. 2003. Atmospheric impact of the 1783-1784 Laki eruption: part II climatic effect of sulphate aerosol. Atmospheric Chemistry and Physics 3: 1177-1189.

Justo Pastor F. 1830. Biblioteca valenciana de los escritores que florecieron hasta nuestros días: con adiciones y enmiendas a la de $D$. Vicente Ximeno. Imprenta y librería de IldenfonsoMompie: Valencia.

Kaemtz LF. 1843. Cours complet de Meteorologie. Adolphe Delahays: París.

Kington J. 1988. The weather of the 1780s over Europe. Cambridge University Press: Cambridge.

Können GP, Zaiki M, Baede APM, Mikami T, Jones PD, Tsukahara T. 2003. Pre-1872 extension of the Japanese instrumental meteorological observation series back to 1819. Journal of Climate $\mathbf{1 6}$ $118-131$

Lafuente A, Sellés M. 1988. El Observatorio de Cádiz (1753-1831). Ministerio de Defensa: Madrid.

Lee E. 1855. Spain and its climates with a special account of Malaga. WJ Adamas: London.

López Arroyo M. 2004. El Real Observatorio Astronómico de Madrid (1785-1975). Ministerio de Fomento: Madrid.

Luterbacher J, Schmutz C, Gyalistras D, Xoplaki E. 1999. Reconstruction of monthly NAO and EU indices back to AD 1675. Geophysical Research Letters 26(17): 2745-2748.

Madoz P. 1848-1850. Diccionario geográfico-estadístico-histórico de España y sus posesiones de ultramar, Vol. 7. La Ilustracion: Madrid.

Manley G. 1974. Central England temperatures: monthly means 1659 to 1973. Quaterly Journal of the Royal Meteorological Society 100: $389-405$.

Martínez y Montes V. 1852. Topografía médica de la ciudad de Málaga. Malaga: Imprenta Ramón Franquelo.

McDougall A. 1851. The temperature of Malaga, considered as a place of residence for invalids. Medical Times 23: 145-147.

Nicholson SE, Dezfuli AK, Klotter D. 2012. A two-century precipitation dataset for the continent of Africa. Bulletin of the American Meteorological Society 93: 1219-1231.
Nieto de Piña CJ. 1785. Historia de la epidemia de calenturas benignas que se experimentó en Sevilla desde principios de Septiembre hasta fines de Noviembre de 1784. Imprenta Mayor: Seville.

Nieto de Piña CJ. 1786. Memoria de las enfermedades que se experimentaron en la ciudad de Sevilla en el año de 1785. Imprenta Mayor: Seville.

Nieto de Piña CJ. 1787. Memoria de las enfermedades experimentadas en la ciudad de Sevilla en el año de 1786. Imprenta de Vazquez Hidalgo y Compañía: Seville.

Przybylak R, Vizi Z. 2005. Air temperature change in the Canadian artic from the early instrumental period to modern times. International Journal of Climatology 25: 1507-1522.

Pulido M, Nogales T. 1989. Publicaciones periódicas extremeñas 1808-1988. Badajoz: Diputación Provincial.

Rochester TF. 1851. Malaga as residence for consumptive persons. New York Journal of Medicine 7: 349-355.

Rodrigo FS. 2012. Completing the early instrumental weather record from Cádiz (Southern Spain): new data from 1799 to 1803. Climatic Change 111: 697-704. DOI: 10.1007/s10584-011-0174-x

Rodríguez R, Barriendos M, Jones PD, Martín-Vide J, Peña JC. 2001. Long pressure series for Barcelona (Spain). Daily reconstruction and monthly homogenization. International Journal of Climatology 21(13): 1693-1704.

van der Schrier G, Jones PD. 2008. Daily temperature and pressure series for Salem, Massachusetts (1786-1829). Climatic Change 87: 499-515.

Scoresby-Jackson RE. 1862. Medical Climatology. John Churchill: London.

Sontakke NA, Singh N. 1996. Longest instrumental regional and all India summer monsoon rainfall series using optimum observations: reconstruction and update. The Holocene 6: 315-331.

Sontakke NA, Nityanand S, Singh HN. 2008. Instrumental period rainfall series of the Indian region (AD 1813-2005): revised reconstruction, update and analysis. The Holocene 18(7): 1055-1066.

Thordarson T, Self S. 2003. Atmospheric and environmental effects of the 1783-1784 Laki eruption: a review and reassessment. Journal of Geophysical Research 108(D1): 4011. DOI: 10.1029/2001JD002042 Trigo RM, Vaquero JM, Alcoforado MJ, Barriendos M, Taborda J, García-Herrera R, Luterbacher J. 2009. Iberia in 1816, the year without summer. International Journal of Climatology 29: 99-115. DOI: $10.1002 /$ joc. 1693

Vaquero JM, García-Herrera R, Wheeler D, Chenoweth M, Mock CJ. 2008. A historical analog of 2005 hurricane Vince. Bulletin of the American Meteorological Society 89(2): 191-201.

Wang B, Jhun JG, Noon BK. 2007. Variability and singularity of Seoul, South Korea, rainy season (1778-2004). Journal of Climate 20: $2572-2580$.

Weyler y Laviña F. 1854. Topografía de las Islas Baleares y en particular de la de Mallorca. Imprenta de Pedro José Gelabert: Palma de Mallorca.

Wheeler D. 1995. Early instrumental weather data from Cádiz: a study of late eighteenth and early nineteenth century records. International Journal of Climatology 15: 801-810.

Wheeler D. 2006. The Gibraltar climatic record: part $1-$ the history of weather observations. Weather 61: 36-39.

Wheeler D. 2007. The Gibraltar climatic record: part 2 - precipitation. Weather 62: 99-104.

Wheeler D. 2011. The Gibraltar climatic record: part 3 - temperature. Weather 66: 259-265.

Wheeler D, Bell A. 2012. The Gibraltar climatic record - Part 4. The earliest records. Weather 67(9): 240-245.

Zaiki M, Können GP, Tsukahara T, Jones PD, Mikami T, Matsumoto K. 2006. Recovery of nineteenth-century Tokyo/Osaka meteorological data in Japan. International Journal of Climatology 26: 399-423. 